\title{
PEMANFAATAN MEDIA POHON ANGKA UNTUK MENGENAL KONSEP BILANGANPADA ANAK USIA DINI
}

\author{
Sariyanti La Sule ${ }^{1}$, Rosita Wondal ${ }^{2}$, Nurhamsa Mahmuud ${ }^{3}$ \\ Universitas Khairun \\ Fakultas Keguruan dan Ilmu Pendidikan \\ Jl. Bandara Sultan Babullah Kota Ternate Utara, Kode Pos 53 Ternate 97728 \\ Telepon: (0921) 3110905- faksimili 09213110901 \\ Email: sariyantilasule@gmail.com ${ }^{1}$, Rositawonda80@gmail.coml2, \\ Nurhamsaaca@gmail.com ${ }^{3}$
}

\begin{abstract}
Abstrak: Pemanfaatan media pohon angka pada anak usia dini adalah suatu kegiatan yang pemanfaatan media pohon angka yang dimainkan anak untuk mengenal konsep bilangan pada anak sejak dini. Pemanfaatan media pohon angka ini bertujuan untuk mengenalkan konsep bilangan berdasarkan pemahaman anak pada indikator 1-10 dengan cara anak menunjukan angkaangka pada pohon angka. Media pohon angka ini dapat menolong anak dalam mengenal konsep bilangan 1-10 dengan tampilan yang menarik. Dalam kajian ini penulis mengunakan metode literatur dengan pengumpulan data pustaka, buku-buku, serta artikel yang terkait dengan penelitian. Berdasarkan kajian yang dilakukan penulis menyimpulkan bahwa pemanfaatan media pohon angka dapat membantu anak dalam mengenal konsep bilangan khususnya angka 1-10.
\end{abstract}

Kata kunci: Media Pohon Angka, Konsep Bilangan

Abstract: The using media of numerals, the tree is an activity to introduce the numbers to early childhood. The main purpose of using the numerals tree is to introduce the numbers based on the children's understanding at an indicator of 1-10 throughout showing the numbers at the numerals tree. This method can help children to know the concept of numbers 1-10 with an interesting display. In this research, the author used the literature of methodology by literature collections, the articles regarding this research. Based on the results, the author concluded that using media of numerals tree can help children master the numbers in especially at 1-10.

Keywords: Media of Numerals Tree, Concept of Numbers

\section{A. Pendahuluan}

Anak-anak adalah ciptaan Allah (SWT) yang sangat unik. Masa kanak-kanak adalah masa dimana anak-anak membutuhkan stimulasi yang sangat baik dalam tahap pertumbuhan dan perkembangannya. Anak-anak adalah sosok individu yang aktif, mereka akan selalu ingin tahu apa yang mereka lihat dan mereka dengar karena mereka sedang dalam proses tahap perkembagan yang sangat pesat. Memberikan stimulasi pada anak adalah suatu hal yang sangat membantu anak dalam tahap perkembangannya, karena anak yang distimulasi dengan baik maka bukan hanya satu aspek perkembangannya saja yang akan berkembang tetapi semua aspek perkembangannya akan berkembang dengan baik karena pada masa ini adalah masa yang paling awal untuk mengembangkan seluru aspek perkembangan pada anak.

Usia dini merupakan usia yang efektif untuk mengembangkan berbagai potensi yang dimiliki anak. Upaya pengembangan berbagai potensi tersebut dapat dilakukan 
dengan berbagai cara. Lembaga pendidikan anak usia dini (PAUD) bertujuan untuk mempersiapkan anak dengan memperkenalkan berbagai aspek pengetahuan, sikap maupun perilaku kepada anak-anak dengan cara yang menyenangkan dalam konteks bermain sehingga anak merasa nyaman dan siap untuk melanjutkan ke jenjang pendidikan selanjutnya.Setiap individu termasuk anak usia dini memiliki keunikan tersendiri. Keunikan yang dimiliki anak usia dini itulah yang membedakan tiap anak walaupun memiliki usia biologis yang sama. Oleh sebab ituproses dalam pembelajaran pun dipandang perlu untuk dikhususkan. Guru perlu memfasilitasi atau mengembangkan semua aspek perkambangan anak (nilai agama dan moral, fisik motorik, bahasa, kognitif, social emosional dan seni). Anak usia dini yang berkembang pada masa peka (sensitive periods), selalu aktif dalam beraktifitas dan rasa ingin tahunya yang besar sehingga merupakan kesempatan yang berharga dalam mengembangkan segala potensi yang terdapat dalam diri anak.

Kegaitan pembelajaran pada lembaga pendidikan anak usia dini dikemas dalam bentuk permainan dengan tujuan agar anak tidak merasa sedang belajar. Rahayu dkk (2019) menyatakan pembelajaran yang menyenangkan akan lebih mudah dipahami dan diingat oleh anak sehingga anak mampu untuk mengetahui dan memahami konsep bilangan dan lambang bilangan.Hasil penelitian tindakan kelas yang telah dilaksanakan melalui beberapa tindakan dari Siklus I dan II menunjukan bahwa implementasi APE pohon angka dapat meningkatkan kemampuan mengenal konsep dan lambang bilangan pada anak usia 4-5 tahun di PAUD Kumara Widya Sulangai.

Dalam penelitian kajian ilmiah ini penulis mengkaji tentang manfaat media pohon angka dalam memperkenalkan konsep bilangan pada anakusia dini melalui aktivitas bermain dalam kehidupan sehari-hari dan bersifat alamiah. Hal ini dilakukan dengan asumsi bahwa dalam mengenalkan konsep bilangan pada anak merupakan sesuatu proses yang sulit bagi anak khususnya dalam rangka meningkatkan pengetahuan dasar matematika yaitu anak belajar mengenal konsep bilangan dengan menggunakan benda-benda yang menarik bagi anak yakni melalui bermain dengan menggunakan media pohon angka. Pemanfaatan media pohon angka ini dapat dimainkan berdasarkan pemahaman anak saat menghitung angka.Kegiatan ini dilakukan dengan menunjukan angka-angka yang dihitung oleh anak pada indikator menyebutkan bilangan 1-10. Pemanfaatan media pohon angka bertujuan untuk memudahkan anak dalam mengenal lambang bilangan 1-10 dengan cara yangmenarik dikemas dalam bentuk kegiatan bermain yang dilakukan di dalam kelas.

\section{B. Pembahasan}

\section{Konsep Bilangan Pada Anak Usia Dini}

Kata konsep menurut kamus besar bahasa Indonesia adalah suatu rancangan. Dalam konteks penelitian ini adalah rancangan kerja otak dalam memahami tentang bilanganyang akan menjadi dasar bagi penguasaan konsepkonsep matematika selanjutnya di jenjang pendidikan formal. Bilangan merupakan suatu abstraksi, yaitu konsepsi atau buah pikiran manusia yang hanya ada didalam pikiran manusia itu sendiri, atau dapat dikatakan bahwa bilangan itu salah satu unsur yangtidak dapat didefinisikan karena tidak dapat dijelaskan degan kata-kata, sesuatu yang berhubungan dengan jumlah/ nilai/ banyak. 
Timbulnya konsep tersebut dikarenakan keinginan manusia untuk mengetahui banyaknya benda-benda yang berada dalam suatu himpunan benda-benda, baik benda itu konkrit maupun abstrak. Bilangan dapat digunakan dengan tujuan menggambarkan objek atau kejadian di sekitar kita. Bilangan dapat menyatakan kuantitas, urutan atau nama sesuatu (Komariah 2013).

Bilangan adalah suatu konsep matematika yang digunakan untuk pencacahan dan pengukuran. Bilangan bersifat abstrak. Bilangan memberikan keterangan mengenai banyaknya sesuatu. Menurut Suparmo mengatakan bahwa bilangan adalah satuan dalam sistem matematika yang dapat dioperasionalkan secara matematik. Bilangan adalah suatu konsep matematika yang sangat penting untuk dikuasai oleh anak karena menjadi dasar bagi penguasaan konsep matematika selanjutnya di jenjang pendidikan formal berikutnya.Bilangan dan angka merupakan dua hal yang berbeda. Bilangan mewakili banyaknya suatu benda. Simbol ataupun lambang yang digunakan untuk mewakili suatu bilangan disebut sebagai lambang bilangan atau angka. Angka adalah suatu lambang tertulis sebagai anggota dari suatu sistem penghitungan dan pengukuran (Irfatul Ulum, 2014).

Sudaryanti mengungkapkan bahwabilangan adalah suatu obyek matematika yang sifatnya abstrak dan termasuk kedalam unsur yang tidak didefinisikan, maka diperlukan adanya simbol atau lambang untuk mewakili suatu bilangan. Untuk menyatakan bilangan dinotasikan dengan lambang bilangan yang disebut angka. Bilangan berkenaan dengan nilai. Angka hanya merupakan suatu notasi tertulis dari sebuah bilangan. Angka adalah simbol yang mewakili jumlah,untuk dapat menguasai nya maka anak harus bentuk dari masing-masing simbol. Hanya ada sepuluh simbol dasar, yaitu: 1, 2, 3, 4, 5, 6, 7, 8, 9 dan 0, sedangkan bilangan adalah jumlah yang menunjukkan banyaknya benda/peristiwa saat dihitung, untuk dapat menguasainya maka anak harus memahami konsep dari masing-masing jumlah (Budiartini ddk 2014).

Konsep bilangan adalah himpunan benda-benda atau angka yang dapat memberikan sebuah pengertian. Konesp bilangan selalu dikaitkan dengan pekerjaan menghubunghubungkan baik benda maupun dengan lambang bilangan". Pernyataan diatas menjelaskan bahwa konsep bilangan perlu dikenalkan kepada anak sejak dini, karena pemahaman konsep bilangan akan menjadi dasar bagi penguasaan konsep-konsep matematika selanjutnya. Konsep bilangan juga merupakan himpunan benda-benda atau angka yang dapat memberikan sebuah pengerti. (Ramaini dalam Rahman, dkk. 2017)

Reni (2016) mengungkapkan bahwa konsep bilangan adalah himpunan benda-benda atau angka yang dapat memberikan sebuah pengertian. Konsep bilangan ini selalu dikaitkan dengan pekerjaan menghubung-hubungkan baik benda-benda maupun dengan lambang bilangan. Cara-cara yang dapat dilakukan di Taman Kanak-kanak dalam pengenalan konsep bilangan antara lain dengan menggunakan sarana pendukung yang berupa alat peraga atau alat permainan yang dapat digunakan oleh anak maupun guru dalam kegiatan pembelajaran.

Sofyan (2016) menyatakan bahwa Konsep bilangan adalah himpunan benda-benda atau angka yang dapat memberikan sebuah pengertian. Konsep 
bilangan ini selalu dikaitkan dengan pekerjaan menghubung-hubungkan baik benda-benda maupun dengan lambang bilangan

Menurut Hurlock bahwa seiring dengan perkembangan pemahaman bilangan permulaan, konsep yang mulai dipahami anak sejalan dengan bertumbahnya pengalaman yang dimiliki anak diantaranya konsep bilangan.Konsep bilangan berhubungan dengan kata-kata, ketika anak mulai berbicara. Konsep bilangan akan berkembang dengan cepat sampai pada peningkatan ke tahap pengertian mengenai jumlah, konsep bilangan ini berhubungan dengan penambahan dan pengurangan (Susanto 2012).

Menurut Depdiknas dalam Nur Latifa dkk, (2011) terdapat tiga tahapan dalam pembelajaran matematika yaitu: a) penguasaan konsep, b) masa transisi, c) lambang bilangan. Pengetahuan tentang matematika sebenarnya sudah bisa diperkenalkan sejak usia dini (0-6 tahun) dengan mengenalkan bilangan. Matematika sebagai ilmu tentang bilangan, hubungan antara bilangan dan prosedur operasional yang digunakan sebagai bilangan.

Anita Yus (2005) menyebutkan anak TK memiliki kemampuan sebagai berikut:

a. Menyebut urutan bilangan dari 1-10

b. Menghitung (mengenal konsep bilangan dengan benda-benda)

c. Menghubungkan konsep bilangan dengan lambang bilangan (anak tidak disuruh menulis)

d. Mengenal konsep bilangan sama dan tidak sama, lebih dan kurang, banyak dan sedikit

e. Menyebutkan benda yang berbentuk geometri

f. Mengelompokkan lingkaran, segitiga, dan segi empat

g. Menyusun kepingan puzzle menjadi bentuk utuh (4-6 bagian)

h. Mengenal ukuran panjang, berat, dan isi

i. Mengenal alat ukur mengukur

j. Menyatakan waktu yang dikaitkan dengan jam

k. Mengenal penambahan dengan benda-benda 1-10

l. Mengenal pengurangan dengan benda-benda 1-10

m. Mengurutkan benda 1-10 berdasarkan urutan tinggi-rendah, besar-kecil, beratringan, tebal-tipis

n. Memperkirakan urutan berikutnya setelah melihat bentuk 3 pola yang berurutan

o. Meniru pola dengan menggunakan 4 kubus

p. Mengerjakan mencari jejak (maze) yang lebih rumit

Standar tingkat pencapaian perkembangan anak usia 5-6 tahun yang berkaitan dengan kemampuan matematika (berhitung) seperti yang termuat dalam lampiran 1 Permendikbud No. 137 tahun 2014 tentang Standar Nasional Pendidikan Anak Usia Dini dalam lingkup perkembangan kognitif pada kemampuan berpikir logis dan simbolik antara lain:

a. Mengenal perbedaan berdasarkan ukuran: "lebih dari", "kurang dari", dan "paling/ter"

b. Mengklasifikasikan benda berdasarkan warna, bentuk, dan ukuran (3 variasi) 
c. Mengklasifikasikan benda yang lebih banyak ke dalam kelompok yang saman atau kelompok yang sejenis, atau kelompok berpasangan yang lebih dari 2 variasi

d. Mengenal pola ABCD-ABCD

e. Mengurutkan benda berdasarkan ukuran dari yang paling kecil ke paling besar atau sebaliknya

f. Menyebutkan lambang bilangan 1-10

g. Menggunakan lambang bilangan untuk berhitung.

h. Mencocokan bilangan dengan lambang bilangan

Visualisasi operasi hitung ini memudahkan anak untuk memahami konsep penjumlahan.Sehingga mereka tidak perlu berpikir abstrak dan membayangkan sesuatu yang tidak memiliki bentuk. Karena pada pertumbuhan anak usia 2-7 tahun, anak belum dapat memahami segala sesuatu yang bersifat abstrak. Segala sesuatu harus dikongkritkan agar dapat dipahami oleh system kerja otak anak (praoperasional). (Alfiyah dkk, 2011).

Kemampuan pemahaman konsep bilangan anak dapat memalui tahapan yaitu tahap pemahaman dan pengertian tentang sesuatu dengan menggunakan benda dan peristiwa konkrit seperti pengenalan warna, bentuk, dan menghituan bilangan, tahap transisi yaitu proses berfikir yang merupakan masa peralihan dari pemahaman konkrit menunju pengenalan lambang yang abstrak. Menurut Robbins (Rahayu dkk 2019) kemampuan merupakan bawaan kesanggupan sejak lahir atau merupakan hasil dari latihan yang digunakan untuk melakukan suatu pekerjaan. Kemampuan tersebut meliputi kemampuan fisik dan kemampuan intelektual. Kemampuan fisik berkaitan dengan stamina dan karakteristik tubuh, sedangkan kemampuan intelektual berkaitan dengan aktivitas mental. Sedangkan Sinaga dan Hadiati mendefenisikan kemampuan sebagai suatu dasar seseorang yang dengan sendirian berkaitan dengan pelaksanaan pekerjaan secara efektif atau sangat berhasil.Sejalan dengan yang diungkapkan Hurlock dalam Reni (2016) memahami konsep bilangan melalui permainan sangat penting karena dengan permainan anak akan dapat cepat memahami maksud dari pembelajaran tersebut.

Dari uraian di atas maka dapat disimpulkan bahwa pengenalan konsep bilangan pada anak dalam kajian ini adalah pemahaman anak tentang angka 1 sampai dengan 10 yang diaktualisasikan dengan cara menyebut angka yang dipahami.

\section{Bermain dengan Media Pohon Angka}

a. Bermain Pada Anak Usia Dini

Menurut Abidin (2009) bermain merupakan dunia anak-anak, tempat dengan siapa mereka bertemu, beraktivitas dan berkreativitas. Walaupun mereka tidak saling mengenal, mereka berkumpul bersama untuk bermain. Melalui bermain mereka akan saling mengenal dan berinteraksi dengan bahasa mereka. Melalui bermain mereka juga akan belajar tentang kehidupan, melatih keberanian sehingga menumbuhkan rasa kepercayaan diri, serta belajar menghargai teman sesamanya. 
b. Media Pohon Angka

1) Media Pembelajaran

Media pembelajaran mempunyai peranan yang penting dalam proses kegiatan belajar mengajar. Dengan adanya media, proses kegiatan belajar mengajar akan semakin dirasakan manfaatnya. Penggunaan media diharapkan akan menumbuhkan dampak positif, setiap munculnya proses yang lebih kondusif, terjadinya umpan balik dalam proses belajar mengajar,dan mencapai hasil yang optimal. Menurut Arsyad dalam Guslinda dkk, (2018) mengatakan Istilah media berasal dari bahasa latin yang merupakan bentuk jamak dari "medium" yang secara harfiah berarti perantara atau pengantar. Secara umum adalah segalah sesuatu yang dapat menyalurkan informasi dari sumber informasi kepada informasi.Istilah media dikenal dalam bidang komunikasi, sehingga media yang digunakan dalam pembelajaran disebut media pembelajaran. Adapun pengertian media pembelajaran menurut para ahli:

Menurut Heinich dalam Fita (2018) media merupakan alat saluran komunikasi. Media berasal dari bahasa latin dan merupakan bentuk jamak dari kata "medium" yang secara harfiah berarti "perantara" yaitu perangkat sumber pesan (a source) dengan penerimaan pesan (a receiver). Hairudin mengungkapkan berpendapat media bahwa segala sesuatu yang dapat menyalurkan informasi dari sember kepada penerima.Serta untuk mencapai tujuan pembelajaran tertentu yang sudah dirumuskan (Wahyuni dkk, 2013).Sedangkan Menurut Kamus Besar Bahasa Indonesia media pendidikan adalah alat dan bahan yang digunakan dalam proses pengajaran atau pembelajaran.

Tresnawati mengungkapkan bahwa kata media dari bahasa latin Medius yang secara harfia perantara atau pengaturan. Dalam bahasa Arab, media adalah peraturan atau pegetahuan pesan dari pengirim kepada penerima pesan. Dalam proses belajar mengajar kehadiran media mempunyai arti yang cukup penting. Karena dalam kegiatan tersebut ketika pelaksanaan bahan yang disampaikan dapat dibantu dengan menghadirkan media sebagai perantara. Media dapat mewakili apa yang kurang mampu guru ucapkan melalui kata-kata atau kalimat tertentu. Bahkan keabstrakan bahan dapat dikontrolkan dengan kehadiran media pembelajaran (Angung dkk, 2015)

Cara berfikir anak usia dini sangat berbeda dengan cara berfikir orang dewasa. Cara berfikir anak usia dini kadang kala tidak masuk akal dan membingunkan bagi orang dewasa. Anak akan berpikir secara bersamaan walaupun yang dipikirannya itu tidak ada yang berhubungan. Menurut Piaget anak usia dini berada pada praoperasional yaitu usia 2-6 tahun, dimana anak sudah mulai menggunakan simbol-simbol untuk mempresentasi dunia (lingkungan ). Mengatakan bahwa perkembagan anak usia dini pada tahap ini anak belajar terbaik melalui kehadiran benda-benda. Anak akan berfikir berdasarkan pada pengalaman akan benda-benda konkret. Untuk memfasilitasi perkembagan tersebut maka 
dalam pembelajaran dapat dilakukan dengan penggunaan media pembelajaran. Media selain dapat digunakan untuk mengantarkan pembelajaran secara utuh juga dapat dimanfaatkan untuk menyampaikan bagian tertentu dari kegiatan pembelajaran, memberikan penguatan maupun motivasi. Kembali kepada arti penting media dalam proses belajar mengajar yang dapat mengantarkan kepada tujuan pendidikan belajar mengajar.Pada dasarnya media pembelajaran mempunyai lima bentuk dasar yaitu:

a) suara, gambar, grafik, garis dan gerakan Indra. Berdasarkan bentuk informasi yang digunakan, media pembelajaran dibagi dalam lima macam, yaitu: Media visual diam Merupakan media yang dapat diterima oleh indera penglihatan yang tidak bergerak, misalnya foto, kartu.

b) Media visual bergerak Merupakan media yang dapat diterima oleh indera penglihatan yang bergerak, misalnya film tanpa suara.

c) Media audio Merupakan media yang dapat diterima dengan indera pendengaran, misalnya tape, audio.

d) Media audio visual diam Merupakan media yang dapat diterima dengan indera penglihatan maupun pendengaran, tetapi tidak bergerak, misalnya sound slide atau film strip bersuara.

e) Media audio visual gerak Merupakan media yang dapat diterima oleh indera pendengaran dan penglihatan dan dapat bergerak, misalnya film bersuara, televisi, dan lain-lain. Media dapat disajikan dalam bentuk penglihatan langsung, proyeksi optik, proyeksi elektronik atau telekomunikasi (Watik 2015:120)

2) Pohon angka

Kemampuan anak untuk mengenal angka memerlukan konsep berpikir tentang objek, benda, atau kejadian.Anak mulai mengenal simbol (kata-kata, angka, gerak tubuh, atau gambar) untuk mewakili benda-benda yang ada di lingkungannya. Karena cara berpikir anak masih tergantung pada objek konkrit serta tergantung pada rentang waktu kekinian dan tempat dimana ia berada, mereka belum dapat berpikir secara abstrak sehingga memerlukan simbol yang konkrit saat guru menanam suatu konsep kepada anak usia dini (Nurul 2014).

Menurut Tadkirotun (Fitria dkk, 2018) mengatakan angka atau bilangan adalah lambang atau simbol yang merupakan suatu objek yang terdiri dari angka-angka. Sebagai contoh bilangan 10, dapat ditulis dengan dua buah angka (double digits) yaitu angka 1 dan angka 10). Bilangan banyak ditemui dalam kehidupan sehari-hari. Namun demikian, bilangan yang ditemui anak-anak sebenarnya memiliki arti yang berbeda-beda.

Angka 1 sampai 10 ini adalah angka pertama yang digunakan seluruh manusia ketika masa anak sebelum mengenal bilangan lain yang lebih besar. Angka 1-10 ini adalah pendidikan pengenalan angka diawal. Padamasa ini terjadi perkembangan fisik yang sangat pesat. Menurut Wardani (Rawa dkk, 2019:10) mengungkapkan bilangan angka merupakan 
suatu konsep tentang bilangan angka 1 sampai 10 sebagai angka pemula yang terdapat unsur-unsur penting seperti nama, urutan, bilangan dan Jumlah. Indikator yang berkaitan dengan kemampuan mengenal bilangan angka yaitu:

a) Counting (berhitung),

b) One-to-one correspondence(koresponden satu-satu),

c) Quality(kuantitas),

d) Comparison(perbandingan)

e) Recognizing and writing numeral(mengenal dan menulis angka)

Menurut Departemen Pendidikan Nasional kemampuan mengenal angka pada permulaan berhubungan dengan berbagai percobaan atau demontrasi sebagai suatu pendekatan secara ilmiah atau logis dengan tetap mempertimbangkan tahapan berpikir anak. Fitjrof Capra mengatakan bahwa pengetahuan manusia tentang mengenal angka dan perhitungan, masyarakat, dan kebudayaan telah(Nurrahamadani dkk 2017)

Berhitung merupakan salah satu kemampuan akademik dasar yang mulai diajarkan pada pendidikan anak usia dini. Kemampuan berhitung berkaitan dengan perkembangan aspek kognitif pada tumbuh kembang anak usia dini. Karena itulah, tidak heran jika anak-anak TK zaman sekarang sudah diajari operasi hitung dasar seperti penjumlahan dan pengurangan. Alat media pohon angka adalah salah satu media yang bisa kita gunakan untuk mengajari anak TK cara berhitung yang tepat. Selain memiliki bentuk yang menarik, pohon angka juga memiliki konsep yang mudah dipahami oleh anak. Lalu, bagaimana cara membuat media pembelajaran berupa pohon angka yang menarik. (dalam wykke 2017:20)

Media pohon angka adalah salah satu media yang dapat digunakan untuk pembelajaran ditaman kanak-kanak yang merupakan permainan edukasi untuk melatih berhitung anak-anak melalui permainan edukatif. Media ini adalah alat permainan edukasi (APE). Untuk kelompok pendidikan anak usia dini (PAUD). Pohon juga dapat digunakan untuk melatih kemampuan kognitif anak salah satunya untuk mengenalkan lambang bilangan dan konsep bilangan ( Budiartini dkk, 2014)

Permainan dengan pohon hitung memiliki manfaat-manfaat adalah sebagai berikut :

a) Melatih berhitung pada anak.

b) Mengenalkan angka pada anak.

c) Pengenalan aneka benda pada anak.

d) Melatih kreativitas, motorik halus dan emosi pada anak.

e) Memberi pembelajaran pada anak berdasarkan konsep matematika yang benar.

f) Menghindari ketakutan matematika pada anak sejak awal.

g) Membantu anak belajar matematika secara alami melalui kegiatan bermain. 
Kelebihan pembelajaran dengan permainan pohon hitung adalah sebagai berikut :

a) Bentuknya yang unik sehingga anak akan menyukai pembelajaran dengan menggunakan pohon hitung.

b) Pohon hitung ditempeli gambar buah yang berwarna cerah sehingga visualisasinya sangat menarik. Hal tersebut menarik perhatian anak sehingga anak akan antusias dan lebih aktif untuk mengikuti permainan ini.

c) Pohon hitung dimainkan secara kelompok. Dalam pembelajaran menggunakan pohon hitung secara kelompok anak akan bergerak aktif dan berpikir cepat, anak berusaha memecahkan masalah dan melatih kerjasama dengan teman-teman.

Sedangkan kekurangan pembelajaran dengan permainan pohon hitung adalah sebagai berikut:

a) Pohon hitung dimainkan secara kelompok dimana kemungkinan terjadinya perselisihan antar anak akan terjadi seperti memperebutkan gambah buah.

b) Anak cenderung tidak sabar untuk melakukan sendiri permainan dengan pohon hitung sehingga ketertiban dalam kelompok akan sedikit sulit untuk diterapkan.

c) Guru dituntut untuk dapat membagi perhatian secara optimal kepada tiap kelompok agar pembelajaran dengan menggunakan pohon hitung dapat berlangsung dengan baik (Wahyuni dkk, 2016).

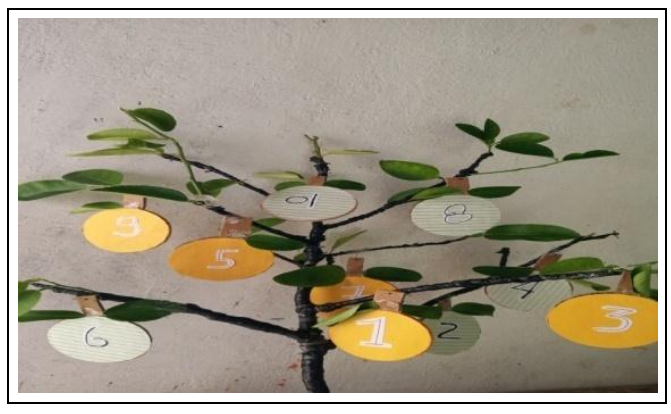

Gambar 1. Media Pohon Angka

Cara Pembuatan media Pohon angka adalah sebagai berikut:

a) Alat dan bahan:

- Kertas karton warna-warni

- Kertas

- Lem

- Gunting dan pisau cutter

- Spidol

- Selotip bening

- Kardus

- Ranting lemon 
b) Proses pembuatan:

- Gambar pola batang pohon menggunakan spidol di atas kertas karton. Gunting dan temple pada gardus

- Potong pola batang pohon pada gardus menggunakan pisau cutter atau gunting, kemudian ditempelkan

- Gambar pola bentuk 1-10 di atas kertas, kemudian gunting pola tersebut, dan tempelkanpada atas karton warna-warni

- Selotip setiap angka dengan selotip bening agar lebih tahan lama.

- Ukuran disesuaikan dengan kebutuhan.

Penelitian-penelitian terdahulu yang terkait dengan kajian literatur ini adalah sebagai berikut:

1. Penelitian Budiartini, dkk(2014) dengan judul "Penerapan Metode Pembelajaran Tugas Berbrntuk Media Pohon Angka Untuk Meningkatkan Kemampuan Mengenal Lambang Bilangan Anak". Berdsarkan hasil penelitian PTK ini menunjukan bahwa dengan penerapan metode pemberian tugas berbentuk media pohon angka dapat meningkatkan pada anak kelompok B di TK Kuncup Harapan Banjar berhasil dengan baik peningkatan kemampuan mengenal lambang bilangan anak pada kelompok B pada siklus II sebesar 80,8\%. Data ini menunjukkn ada peningkatan kemampuan mengenal lambang bilangan anak kelompok B dari siklus I ke siklus II sebesar 23\%.

2. Penelitian yang dilakukan oleh Margithawati, dkk (2015) dengan judul "Penerapan Metode Pemberian Tugas Berbentuk Media Pohon Hitung Untuk Mengetahui Perkembangan Kognitif Anak Kelompok B1". Berdasarkan hasil analisis data menunjukkan bahwa terjadi peningkatan perkembangan kognitif anak dengan melalui metode pemberian tugas berbantuan media pohon hitung pada siklus I sebesar $60,50 \%$ yang berada pada kategori rendah dan mengalami peningkatan pada siklus II menjadi $85,25 \%$ yang tergolong pada kategori tinggi. Jadi, terjadi peningkatan hasil kegiatan belajar dalam perkembangan kognitif pada anak sebesar $24,75 \%$.

3. Penelitian yang dilakukan oleh Rawa, dkk (2019) dengan judul "Pengaruh Media Pembelajaran Pohon Angka Terhadap Kemampuan Mengenal Konsep Bilangan Pada Anak Usia 5-6 Tahun Di TKK Satap st. Theresia Wolomeli Kabupaten Ngada". Berdasarkan penelitian media pembelajaran pohon angka pada tabel One-Sample Statistic variable Y lebih besar dari variabel X $(14.86>8.000)$ berdasarkan hasil analisisi data tersebut dinyatakan ada pengaruh media pembelajaran pohon angka terhadap kemampuan mengenal konsep bilangan pada anak usia 5-6 tahun.

4. Nurrahmadani dkk (2017) menyimpulkan bahwa perkembangan kemampuan kognitif anak dalam mengenal angka pada prasiklus terdapat bahwa 6 anak belum berkembang (BM), 5 anak mulai berkembang (MB), 2 anak yang berkembang sesuai harapan (BSH), belum ada anak yang berkembang sangat baik (BSB). Hasil Siklus 1 terdapat bahwa kemampuan kognitif anak berkembang sangat baik (BSB) sebanyak 4 anak dan berkembang sesuai harapan (BSH) sebanyak 4 anak, yang mulai berkembang (MB) terdapat 3 anak, belum berkembang (BB) terdapat 2 anak. Pada siklus 1 meningkat 8 anak dan pada siklus II anak mengalami peningkatan yaitu berkembang sangat baik (BSB) sebanyak 6 anak, yang 
berkembang sesuai harapan (BSH) sebanyak 6 anak, mulai berkembang (MB) 1 anak. Pada siklus 1 dan siklus II terdapat 12 anak, dapat disimpulkan bahwa dengan menggunakan media pohon angka dapat meningkatkan kemampuan kognitif anak mencapai $92 \%$.

5. Marfuah dan Heru(2017) menemukan hasil dari penelitiannya bahwa melalui penggunaan media pohon hitung dapat meningkatkan kemampuan mengenal konsep bilangan pada anak usia dini di Kelompok Bermain Pelangi Aisyiyah Jumantoro Karanganyar Tahun Ajaran 2016/2017, hal ini dibuktikan bahwa peningkatan pada siklus I ke siklus II meningkat sebesar 25,03\%, siklus II ke siklus III mengalami peningkatan sebesar 50\% secara keseluruhan kemampuan mengenal bilangan anak telah mencapai 95,83\%. Dengan demikian hipotesis yang menyatakan melalui penggunaan media pohon hitung dapat meningkatkan kemampuan mengenal konsep bilangan pada anak usia dini di Kelompok Bermain Pelangi Aisyiyah Jumantoro Karanganyar Tahun Pelajaran 2016/2017, terbukti kebenarannya.

6. Malapata dkk (2019) melakukan penelitian dengan tujuan untuk meningkatkan kemampuan berhitung anak usia 4-5 tahun melalui media lumbung hitung pada anak kelompok A2 di TK Sinar Nyata Salatiga. Penelitian ini merupakan penelitian tindakan kelas (PTK). Penelitian ini terdiri dari dua siklus dan setiap siklusnya dilaksanakan tiga kali pertemuan. Subjek penelitian ini adalah 13 anak Kelompok A2 TK Sinar Nyata Salatiga. Teknik pengumpulan data melalui observasi dan dokumentasi. Hasil penelitian menunjukan bahwa terdapat peningkatan kemampuan berhitung anak usia 4-5 tahun melalui media "Lumbung Hitung". Proses pembelajaran dengan menggunakan media Lumbung Hitung dapat meningkatkan kemampuan berhitung anak usia 4-5 tahun. Dengan demikian dapat disimpulkan bahwa melalui media Lumbung Hitung dapat meningkatkan kemampuan berhitung pada anak kelompok A2 di TK Sinar Nyata.

Berdasarkan kajian literatur yang dilakukan tergambar bahwa kegiatan bermain anak dengan media pohon angka dapat membantu anak dalam mengenal konsep bilangan.Dengan kegiatan bermain menggunakan angka-angka pada media pohon angka dapat meningkatkan kualitas berpikir anak.Anak dapat mengambil setiap angka pada media pohon angka, menyebutkan angka tersebut serta memasangkan angka pada media pohon angka adalah suatu kegiatan yang manarik serta menyenangkan pada anak.Anak antusias untuk menunjukan dan menyebutkan angkaangka yang tersedia dengan gembiranya.Hal ini sangat membantu anak dalam memahami konsep bilangan khususnya pada angka 1 sampai dengan angka 10 dengan baik dan benar.

\section{Simpulan}

Berdasarkan kajian leteratur yang dilakukan, penulis menyimpulkan bahwa dengan pemanfaatan media pohon angka dapat menolong anak usia dini usia 4 sampai dengan 6 tahun dalam mengenal konsep bilangan khususnya angka 1 sampai dengan 10. Hal ini dapat ditingkatkan pada angka selanjutnya. Dengan demikian disarankan pada guru di lembaga pendidikan anak usia dini untuk dapat menciptakan media-media yang kreatif dan unik untuk menarik perhatian anak saat proses 
pembelajaran. Salah satu rekomendasi dalam memperkenalkan konsep bilangan pada anak usia dini adalah melalui media pohon angka.

\section{DAFTAR PUSTAKA}

Alfiyah dan Sri Joeda Andajani 2011. Peningkatan kemampuan mengenal lambang bilangkan melaluipermainan pohon angka bagi siswa tunagrahita. Artikel jurnal.

Abidin. 2009, Bermain, Rizqi Press, Bandung

Budiartini Desak Putu, I Nyoman Jampel, Nice Maylani Asril 2014. Penerapan Metode Pemberian Tugas Berbantuan Media Pohon Angka Untuk Meningkatkan Kemampuan Mengenal Lambang Bilangan. e-Journal PG-PAUD Universitas Pendidikan Ganesha Jurusan PENDIDIKAN ANAK USIA DINI 2Universitas Pendidikan Ganesha Singaraja, Bali (Volume 2 No 1 Tahun 2014)

Fitria Nila Ockti Syafitri, Rohita, 2018. Peningkatan kemampuan mengenal konsep lambang bilangan 1-10 melalui permainan pohon hitung pada anak usia 4-5 tahun di BKB PAUD harapan bangsa. Universitas Al Azhar Indonesia.

Fita Uly Khusunaya 2018. Penggunaan media permainan kartu angka dalam meningkatkan kemampuan mengenal konsep bilangan pada anak kelompok A di TK islam terpadu tazkia cangkiran mijen. Skripsi Universitas Islam Negeri Walisongo.

Komariah, 2013. MEMPERKENALKAN BILANGAN PADA ANAK USIA DINI. Cakrawala Dini : Vol. 4 No. 2, November 2013

Margitawati Anak Agung Ayu Ratih,. Ketut Pudjawan, Didith Pramunditya Ambara, 2015. Penerapan Metode Pemberian Tugas Berbantuan Media Pohon Hitung Untuk Meningkatkan Perkembangan Kognitif Anak Kelompok B1. Vol 3, No 1 (2015) Jurnal Pendidikan Anak Usia Dini Undiksa.

Marfuah Fitri, Hera Heru , 2017. Upaya Meningkatkan Kemampuan Mengenal Bilangan Pada Anak Usia Dini Menggunakan Media Pohon Hitung Di Kelompok Bermain Pelangi Aisyiyah Jumantoro. Jurnal AUDI, Volume 2, Nomor 1. 2017

Malapata Elisa, Lanny Wijayaningsih, 2019. Meningkatkan Kemampuan Berhitung Anak Usia 4-5 Tahun Melalui Media Lumbung Hitung Volume 3 Issue 1 (2019) Pages 283 - 293 Jurnal Obsesi : Jurnal Pendidikan Anak Usia Dini DOI: 10.31004/obsesi.v3i1.183.

Nurrahmadani, Anizar Ahmad, Yuhasriati, 2017. Memperkenalkan Bilangan Untuk Anak Usia Dini Dengan Menggunakan Media Pohon Angka Di TK Darurrahman Kota Banda Aceh Jurnal Ilmiah Mahasiswa Pendidikan Guru Anak Usia Dini, 2(1):70-75 Mei 2017.

Nur Latifah, Arie Supriyanto, Khusnul Laely 2011. Meningkatkan kemampuan mengenal bilangan melalui media pohon hitung flannel. Jurnal Universitas Muhamadiyah Magelang.

Nurul Mita Chotul Chold 2014. Meningkatkan kemampuan berhitung melalui media pohon hitung pada anak kelompok B TK kasuma mulia kecamatan pare. Universitas PGRI Kendiri.

Nurrahamadani, Anzar Ahmad, Yuhasriati 2017. Memperkenalkan bilangan untuk anak usia dini dengan menggunakan media pohon angka di TK darurrahman kota banda 
aceh, Universitas Syiah Kuala Darsussalam Banda Aceh Indonesia

Rahayu Made Ayu Nadi, Putu Indah Lestari, Made Elia Cahya, 2019. Implementasi alat permainan edukatif pohon angka dalam meningkan kemampuan mengenal konsep dan lambang bilangan. Universitas Dhyana Pura,Vol 3, No 1 (2019) Media Edukasi: Jurnal Ilmu Pendidikan

Rahman Taopik, Sumardi , Fitri Fuadatun, 2017. Peningkatan Kemampuan Anak Usia Dini Mengenal Konsep Bilangan Melalui Media Flashcard. Jurnal PAUD Agapedia, Vol.1 No. 1 Juni 2017, page 118-128..

Rawa Natalia Rosalina, Marsianus Meka, dan Virginia Nai. 2019. Pengaruh media pembelajaran pohon angka terhadap kemampuan mengenal konsep bilangan Pada Anak Usia 5-6 Tahun di TKK Satap St. Theresia Wolomeli Kabupaten Ngada. Jurnal edukasi AUD.Vol 5. No.2 Desember 2019

Rahman Taopik, Sumardi, Fitri Fuadatun 2017.Meningkatkan Kemampuan Anak Usia Dini Mengenal Konsep Bilangan Melalui Media Flashcard.

Reni Yulistiana 2016. Upaya Pembelajaran Kemampuan Mengenal Angka 1-10 Pada Anak Di TamanKanak-kanak Kesuma Tanjung Karang Barat Bandari Lampung.Universitas Islam Negeri Raden Intan Lampung.

Susanto Ahmad 2012. Perkembangan anak usia dini. Jakarta kencana

Sofyan Ade 2016. Penggunaan Alat Bermain Konsep Bilangan Dalam Pembelajaran Anak Usia Dini Bina Kelurahan Blita PAUD Mawar Kota Salatiga. https://lib.unnes.ac.id/28441/1/1201411069.pdf

Ulum Irfatul 2014. Peningkatkan pemahaman konsep bilangan melalui permainan memancing angka pada anak kelompok A di masyithoh kalisoka triwidadi pajangan bantul. Skripsi Universitas Negeri Yogyakarta.

Watik 2015. Mengembangkan kemampuan mengurungka bilangan 1-10 mengunakan media pohon hitung pada anak kelompok A PAUD PKK kalimpang. Skripsi, Universitas Nusantara PGRI kendiri.

Wykke Safitra 2017. Meningkatkan kemampuan mengenal lambang bilangan melalui media bermain kartun angka pada anak usia 4 tahun di PAUD baitusshibyaan srumabung. Skripsi Fakultas Tarbiyah dan Ilmu Keguruan Institut Agama Islam Negeri Salatiga. Di Akses 23 Januari 2020

Wahyuni Sri. S, Muhammad Ali, Halida, 2016. Peningkatan Kemampuan Berhitung Melalui Permainan Pohon Hitung Usia 4-5 Tahun Di TK, Jurnal Pendidikan dan Pembelajaran, 2016. https://media.neliti.com/media/publications/213861peningkatan-kemampuan-berhitung-melalui.pdf

Yus Anita. (2011). Peskoran perkembangan belajar anak taman kanak-kanak. Jakarta: Kencana Prenada Media. 